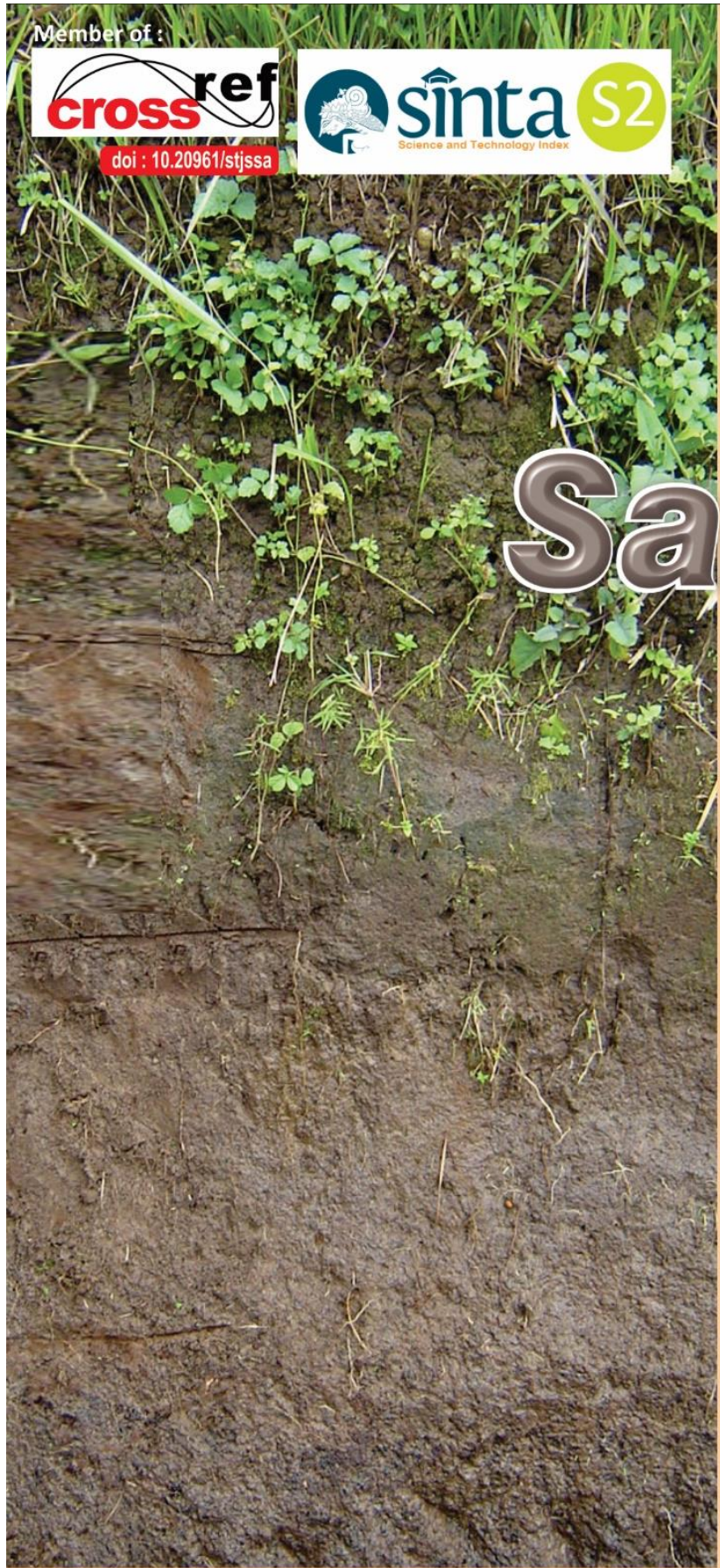

ISSN : 1412-3606

e-ISSN : $2356-1424$

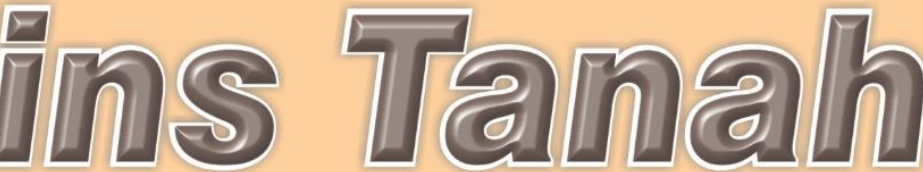
Journal of Soil Science and Agroclimatology ACCREDITED by National Journal Accreditation (ARJUNA) Managed by Ministry of Research, Technology, and Higher Education, Republic Indonesia with Second Grade (Sinta 2) according to the Decree No. 30/E/KPT/2018 (effective until 2021).

\title{
VOLUME 16 ISSUE 2, DECEMBER 2019
}

DOI: http://dx.doi.org/10.20961/stjssa.v16i2
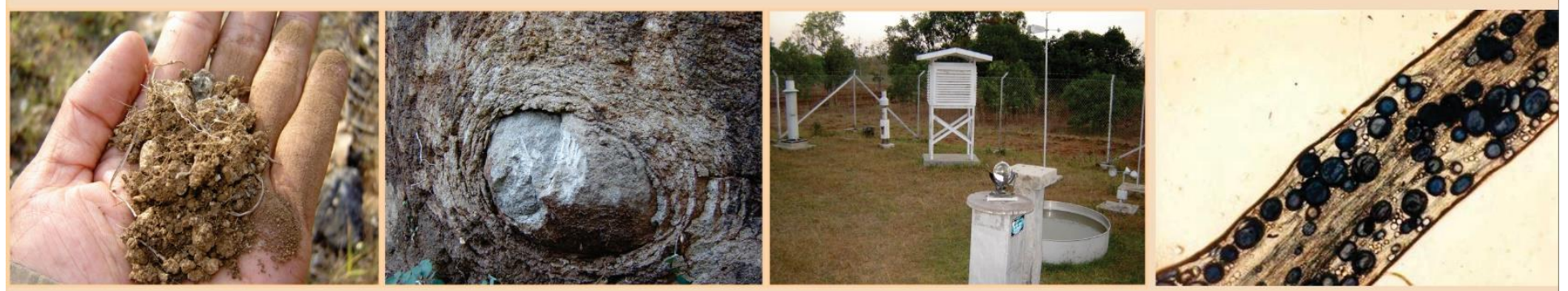

\section{Published bys}

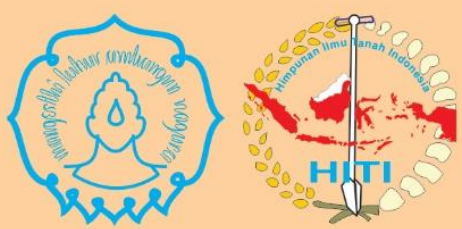

Department of Soil Science, Faculty of Agriculture Universitas Sebelas Maret॰ Surakarta

in Collaboration withs

Indonesian SofllScience Society (HIT))

Regional Commissariat of Centran Javaand Specian Region of Yogyakarta 



\section{EDITORIAL TEAM}

\section{EDITOR IN CHIEF}

Prof. Vita Ratri Cahyani

\section{CO-EDITOR}

Dr. Komariah

Dr. Sudadi

Dr. Jauhari Syamsiyah

Dr. Dwi Priyo Ariyanto
Department of Soil Science, Faculty of Agriculture, Universitas Sebelas Maret; (Scopus Author ID: 6507383077), Indonesia

Department of Soil Science, Faculty of Agriculture, Universitas Sebelas Maret; (Scopus Author ID: 48661102400), Indonesia Department of Soil Science, Faculty of Agriculture, Universitas Sebelas Maret; (Scopus Author ID: 57190729277), Indonesia Department of Soil Science, Faculty of Agriculture, Universitas Sebelas Maret; (Scopus Author ID: 57192415870), Indonesia Department of Soil Science, Faculty of Agriculture, Universitas Sebelas Maret; (Scopus Author ID: 57204939040), Indonesia

\section{ADVISORY INTERNATIONAL EDITORIAL BOARDS}

Prof. Sanjib Kumar Panda

Prof. Jusop Shamshuddin

Prof. Masateru Senge

Dr. Anthony Kent

\author{
EDITORIAL BOARD \\ Prof. Dedik Budianta \\ Prof. Irwan Sukri Banuwa \\ Prof. Dr. Supriyadi \\ Dr. Susilo Hambeg Poromarto \\ Dr. Supyani \\ Dr. Sulakhudin \\ Dr. Benito Heru Purwanto \\ Dr. Eko Hanudin \\ Dr. Dwi Setyawan
}

ASSISTANT EDITOR

Aktavia Herawati

Sidik Pramono
Department of Life Science \& Bioinformatics, Assam University, Silchar; (Scopus Author ID: 57201565767), India

Universiti Putra Malaysia; (Scopus Author ID: 6601937415), Malaysia

Gifu University, Gifu; (Scopus Author ID: 9845622100), Japan International Urban and Environmental Management Program, School of Global Studies, Social Science and Planning, RMIT University, GPO Box 2476, Melbourne, Victoria 3001, Australia

Soil Science Depart, Faculty of Agriculture, Sriwijaya University; (Scopus Author ID: 6506086436), Indonesia

University of Lampung; (Scopus Author ID: 57194420300), Indonesia

Faculty of Agriculture, Universitas Sebelas Maret; (Scopus Author ID: 57190138316), Indonesia

Faculty of Agriculture, Universitas Sebelas Maret, Surakarta; (Scopus Author ID: 6507601450), Indonesia

Department of Plant Protection, Faculty of Agriculture, Universitas Sebelas Maret, (Scopus ID: 56986640100), Indonesia

Department of Soil Science, Faculty of Agriculture, University of Tanjungpura; (Scopus Author ID: 56888768200), Indonesia

Faculty of Agriculture, Gadjah Mada University; (Scopus Author ID: 6507171824), Indonesia

Gadjah Mada University, Yogyakarta; (Scopus Author ID: 57196062767), Indonesia

Department of Soil Science, Faculty of Agriculture, Universitas Sriwijaya, Palembang [Scopus Author ID: 56564118200], Indonesia

Department of Soil Science, Faculty of Agriculture, Univesitas Sebelas Maret; Scopus Author ID: 57201682386), Indonesia

Faculty of Agriculture, Universitas Sebelas Maret, Indonesia 
Available Online at SAINS TANAH Website: https://jurnal.uns.ac.id/tanah/index

SAINS TANAH - Journal of Soil Science and Agroclimatology, 16(1), 2019, ii

\section{EDITORIAL OFFICE}

Department of Soil Science, Faculty of Agriculture, Universitas Sebelas Maret

JI. Ir. Sutami 36A Kentingan Surakarta, Jawa Tengah 57126, Indonesia

Phone/Fax.+62-271-632477 ; Email : sainstanah@uns.ac.id, sainstanahuns@gmail.com

\section{BANK}

BNI 46 Cab. Sebelas Maret Surakarta; Acc : SUDADI; Acc. No. 0448109689

\section{AIMS AND SCOPE}

SAINS TANAH - Journal of Soil Science and Agroclimatology (STJSSA) published the results of research and study in soil science and agroclimatology and other fields related, include:

- Soil physics and conservation

- Soil chemistry and fertility,

- Soil biology and biotechnology

- Clay mineralogy

- Plant nutrient

- Pedogenesis

- Geology and Mineralogy

- Soil survey and classification

- Soil reclamation and remediation

- Agroclimatology

- Environment

\section{INDEXING AND ABSTRACTING}

STJSSA has been registered in the OAI database. Index of this journal:

- Google Scholar http://scholar.google.co.id/citations?user=WhtN6IR7DMQC

- Directory of Open Access Journal https://doaj.org/toc/2356-1424

- Index Copernicus http://jml2012.indexcopernicus.com/Sains+Tanah++Journal+of+Soil+Science+and+Agroclimatology,p24781851,3.html

- Bielefeld Academic Search Engine http://www.base-search.net/Search/Results?q=dccoll:ftunimssurakarta\&refid=dclink

- PKP Index https://index.pkp.sfu.ca/index.php/browse/index/2250

- SINTA (Science and Technology Index) http://sinta.ristekdikti.go.id/journals/detail/?id=1067

- Etc.

STJSSA has been accredited by National Journal Accreditation (ARJUNA) Managed by Ministry of Research, Technology, and Higher Education, Republic Indonesia with Second Grade (Sinta 2) according to the Decree No. 30/E/KPT/2018. 


\section{TABLE OF CONTENTS}

1. Editorial Team

2. Editorial Office

3. Bank

4. Aim and Scope

5. Indexing and Abstracting

6. Table of Contents $127-138$

7. PROCESS AND MINERALOGY OF VOLCANIC MATERIALS ON THE SOUTH SIDE OF THE OLD LAWU VOLCANO IN JAVA ISLAND (Mohammad Nurcholis, Dwi Fitri Yudiantoro, Darban Haryanto, Ahmad Bagus Dianputra, Krishna Aji)

9. CHARACTERISTICS OF CORN COBS WASTE ACTIVATED CARBON FOR SLOW RELEASE MICRO FERTILIZER CARRIER (Priyadi, Windu Mangiring) 147-158

10. ESTIMATION OF SOIL ORGANIC MATTER ON PADDY FIELD USING REMOTE SENSING METHOD (Luthfan Nur Habibi, Komariah, Dwi Priyo Ariyanto, Jauhari Syamsiyah, Takashi S.T. Tanaka)

11. UTILIZATION OF SOIL FUNCTION INFORMATION FOR ASSESSING SOIL QUALITY OF RICE FIELD IN THE QUATERNARY-TERTIARY VOLCANIC TRANSITIONAL ZONES IN CENTRAL JAVA (Ajun Prayitno, Junun Sartohadi, Makruf Nurudin)

12. STUDYING THE RESIDUAL EFFECT OF ZEOLITE AND MANURE ON ALFISOLS CATION EXCHANGE CAPACITY AND GREEN BEAN YIELD (Ahmad Yazid Fudlel, Slamet Minardi, Sri Hartati, Jauhari Syamsiyah)

13. BIOREMEDIATION USING Bacillus subtilis AND Saccharomyces cerevisiae TO REDUCE CHROMIUM IN ELECTROPLATING LIQUID WASTE (Mardiyono, Sajidan, Mohammad Masykuri, Prabang Setyono)

14. POTENTIAL USE OF ALKALINE-ACTIVATED INDONESIAN PUMICE POWDER AS LEAD ADSORBENT IN SOLUTION SYSTEM (Faridlotul Hasanah, Syaiful Anwar, Arief Hartono, Untung Sudadi)

15. THE EFFECTS OF BIOCHAR AND COMPOST ON DIFFERENT CULTIVARS OF SHALLOTS (Allium ascalonicum L.) GROWTH AND NUTRIENT UPTAKE IN SANDY SOIL UNDER SALINE WATER (Rahayu, Jauhari Syamsiyah, Vita Ratri Cahyani, Siti Kharisma Fauziah)

\section{REVIEW ARTICLE}

16. CURRENT EVIDENCE AND FUTURE PROJECTIONS: A COMPARATIVE ANALYSIS OF THE IMPACTS OF CLIMATE CHANGE ON CRITICAL CLIMATE-SENSITIVE AREAS OF PAPUA NEW GUINEA (Patrick S. Michael) 
Available Online at SAINS TANAH Website: https://jurnal.uns.ac.id/tanah/index

SAINS TANAH - Journal of Soil Science and Agroclimatology, 16(1), 2019, iv

17. Cover Page and Author Guidelines

App. 1

18. Publishing Etichal Statement

App. 6

19. Competing Interests Form

App. 8

20. Declaration Of Competing Interests

App. 9

21. Publication Ethics and Malpractice Statement

App. 10

22. Guidelines for Reviewers

App. 13

23. Acknowledgement to Reviewers in this issue

App. 15

24. Submission Information

App. 16 